\title{
POST-MODERN WARS AS A CHALLENGE FOR THE THEORY OF INTERNATIONAL RELATIONS AND INTERNATIONAL LAW
}

\author{
Radosław Zenderowski*, Krzysztof Cebul**
}

\section{Introduction}

Two concepts, nota bene still prevalent in different forms of discourse concerning international affairs, may be used to answer the question about what constitutes the basis of pre-scientific and scientific afterthought on international relations. These are obviously war and peace. Why do wars break out? How to wage wars effectively, i.e. achieve political goals at the smallest possible cost? How to guarantee lasting peace? How to secure peace by making war unprofitable for everyone involved? Finally, which is the natural state, carved into the "genetic code" of interstate relations - peace or war ${ }^{1}$ The above questions have been part of the core of intellectual afterthought within the frames of the theory of international relations and international law.

This paper concerns post-modern war as a social phenomenon, being a subject of scientific research in the area of international relations,

* Professor Radosław Zenderowski, Institute of Political Science Cardinal Stefan Wyszyński University.

** PhD Krzysztof Cebul, Institute of Political Science Cardinal Stefan Wyszyński University.

1 N. Polat, Peace as War, 'Alternatives: Global, Local, Political' 2010, vol. 35, at pp. 317-345. 
international law (ius in bello, ius contra bellum), but also the interdisciplinary scope of conflict research - war studies. The fundamental question is: why and to what extent is the phenomenon of post-modern war not in the existing categorisation and paradigms of the abovementioned sciences? Why do the existing methodological and theoretical tools seem insufficient (which does not automatically make them useless) for the purpose of the analysis of post-modern war? In this paper we, at least partly, try to answer these by firstly, analysing the conditions and genesis of post-modern wars; secondly, indicating precise traits of this type of war and defining their differentia specifica, and thirdly, forming nodal problems that present a challenge for the theory of international relations and international law.

\section{Post-modern war and its genesis}

The concept of post-modernity regarding international relations is connected with the gradual deconstruction of the Westphalian Order, which dates back to the mid $17^{\text {th }}$ century and was especially influential between the mid $19^{\text {th }}$ century and the end of the 1980 s, i.e. in the period of the creation and reinforcement of national states, which appeared to supersede multinational empires which gradually became things of the past. Modernity is connected with a number of fundamental changes related to targets, tools, and principles of waging war. First of all, war was defined within the categories of international relations and the right to declare and wage war was held by legal rulers only. Modern war was defined in the categories of political philosophy (Clausewitz) as "an act of violence aimed at forcing the enemy to fulfil our will" and perceived through three traits: rationality, nationality, and target. According to Clausewitz, "a decision to use war machine to wage wars should be made basing on rational calculation made by competent political authorities to reach the set target." The main motivation and target of modern war was to enlarge the ruled area by conquering new territories, which led to enhancing political power. National armies, built mainly of conscripted citizens of the given state, constituted a tool for waging wars. Only they were entitled to take military action against the enemy constituted by enemy soldiers wearing uniforms.

2 P. D. Williams, Wojna, [War], [in:] P.D. Williams (ed.), 'Studia bezpieczeństwa' [Security Studies], transl. W. Nowicki, Kraków 2012, at pp. 149-150. 
As a rule, civilians did not participate in war as the fighting party or the party which is fought against. Modern wars had their logic and widely accepted rules. One could tell when they started and which battles decided their results. During modern wars, the institutions of the declaration of war, ceasefire, or a peace treaty were fully functioning. It was obvious where war was waged. There was a clear difference between the "area of war" the land where acts of war were allowed - and the "theatre of war," where the conflict actually existed. To a certain degree, modern wars resembled a game of chess, in which effectiveness was a result of combining the rules of logic and experience of war. Finally, modern wars were accompanied by the dynamic development of international law, especially anti-war law and war law (law on military conflicts). Although not always obeyed, it undoubtedly constituted an important point of reference for decisions made on the battlefield. The appearance of international courts aimed at ruling in cases concerning war crimes should be perceived as a great success for humanity. However, there should be no doubt that in many cases they used to be (and still are) used as a political weapon in times of peace to settle post-war disputes, and often has nothing to do with justice.

Modern war, described above, together with the end of the Cold War gradually started to be deconstructed. In the contemporary world, the disappearance of war as an interstate conflict can be observed. International statistics from the end of the Second World War leave no doubts. Research into military conflicts performed within the frames of the Uppsala Conflict Data Project (UCDP) shows that the number of conflicts involving government controlled armies (state-based conflicts - conflicts in which a state is at least one of the fighting parties ${ }^{3}$ ) has been systematically decreasing between the beginning of the 1990s and the first decade of the $21^{\text {st }}$ century.

3 Within the frames of this category of conflict, four types are singled out: (a) interstate armed conflicts between or among states; (b) intrastate armed conflicts between government and internal opposition groups (these are: "civil wars fought for power over a state and conflicts around forming states - secessionist wars fought between the government and the opposition connected to some specific part of the foregoing state and aiming at changing its borders"); (c) internationalised intrastate armed conflicts fought between the government (government forces) and internal opposition groups with other states intervening by deploying forces; (d) extrastate armed conflicts fought between the state and the no-state group outside the state's territory. Moreover, based on conflict intensity criteria, the following division was introduced: (a) minor armed conflicts - between 25 and 1,000 casualties a year; (b) wars - over 1,000 casualties a year. Uppsala Conflict Data Project (UCDP), http://www.pcr.uu.se. 
This refers to two types of conflict: intrastate and interstate conflicts. A source of concern is the fact is that there is an increasing number of internal conflicts between governments and internal opposition groups, in which third-party states intervene, using their armed forces. At the same time, in the mid 1970s, out-of-state armed conflicts (so called colonial wars) disappeared completely with the end of decolonisation process. ${ }^{4}$

The tendency to "privatize" (de-state) armed conflicts is well demonstrated in the statistics (see the graph below) relating to non-state armed conflicts. These conflicts include organised collective armed violence, with none of its participants being a recognised independent state (for example, rapid conflict among local communities and battles among warlords or clans).

Fig. 1. Non-state armed conflicts in the world between 1989 and 2013

\section{Non-state Conflicts by Region, 1989-2013}

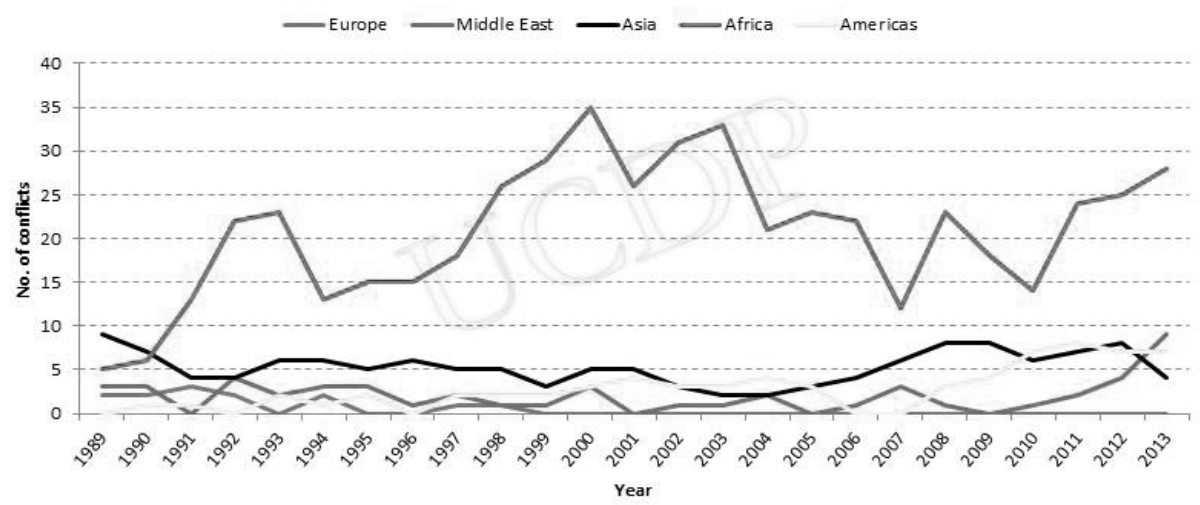

Source: “UCDP Non-state Conflict Dataset v. 2.5-2014 1989-2013" and Sundberg, Ralph, Kristine Eck, and Joakim Kreutz, 2012, “Introducing the UCDP Non-State Conflict Dataset," Journal of Peace Research, March 2012, vol. 49, pp.351-362.

The obvious question about the reasons behind the disappearance of traditional (modern) war, rather than wars in general, arises. On the one hand, political scientists make statements in support of the principle of democratic peace and note that democratic states, as a rule, do not fight against each other, while the increase in the number of democratic states is a fact. This point of view belongs to the liberal paradigm of the theory of

4 Uppsala Conflict Data Project (UCDP), http://www.pcr.uu.se. 
international relations, according to which not only democracy but also and perhaps most importantly - the increase of co-dependence in the economy and politics cause wars to be simply ineffective and unprofitable. According to liberals, also the increase in the global level of education is not without significance. Attention is drawn to the fact that neither territory nor population plays a key role in creating state power anymore. Liberals could also support the thesis of Pierre Hassner, who claimed that a lack of will on the part of the West to wage wars stems from the private and consumerist character of "the developed Western societies, where personal satisfaction and sympathy count more than glory and sacrifice for a common cause." Realists, in turn, apart from the traditional argument about the existence of a relative balance of power at a global and regional scale as a war-preventing factor, add one more argument, which would be also acceptable to liberals. They note that the costs of waging conventional wars are currently too high and no potential benefits can compensate for the incurred expenses and a lack of profit. The appearance of post-modern war should be perceived from this perspective, as the abovementioned factors have not led to the disappearance of wars in general but rather to a change in their character, mainly with respect to techniques and means of waging wars in accordance with the principle of Clausewitz, stating that each era has its own concept of war.

\section{Post-modern war - distinguishing features}

Many different names relating to new types of war have appeared in literature in recent years. Apart from "post-modern war," there is also rebel war, low-intensity war, no-state war, asymmetrical war, dirty war, small war, war without war, irregular war, anonymous war, proxy war, hybrid war, fourth generation war, unrestricted warfare, post-industrial war, post-Westphalian war, and post-Clausewitz war. Additionally, the above list should include the concept of Military Operations Other Than War-MOOTW, formed in the mid 1990s, which includes mainly so-called stabilising missions ${ }^{6}$.

5 P. Hassner, Koniec pewników. Eseje o wojnie, pokoju i przemocy [The end of certainty. Essays on war, peace, and violence], transl. M. Ochab, Warszawa 2002, pp. 55.

6 J.M. Taw, Planning for Military Operations Other Than War: Lessons from US Army Efforts, 'Australian Defence Force Journal' 1999, vol. 134, at p. 57. 
There is no point in focusing on detailed semantic analyses of the ideas mentioned above due to the fact that, while studying the literature of the subject, a strange kind of nonchalance in using these terms can be observed. Sometimes, it turns into a dispute on which of the terms is the most bizarre. For the purposes of this analysis, we assume that the term "post-modern war" is broad enough to include the abovementioned wars, which de facto indicate the selected aspects of post-modern war.

Post-modern wars are still wars, which means that they are unavoidably accompanied by violence aimed at securing specific interests. The forms and tools of violence (the increasing role of symbolic violence) also demonstrate that war targets change. The discussion on whether post-modern wars really constitute a new type of war or if, to some degree, they return to the logic of armed conflicts from before the modern era (the idea of the re-medievalisation of international relations) includes a number of interesting arguments, on which we are, unfortunately, unable to elaborate here. Nevertheless, it is a fact that post-modern wars are in some sense a hybridisation of targets, forms, means, and methods of wars waged in different historical periods. On the other hand, according to Alvin and Heidi Toffler, there are constant clashes of different types of war, as only some of them are waged by both sides in the same way, i.e. by using methods and tools characteristic of a given stage in the development of civilisation. ${ }^{7}$ Before we answer the question about the quality traits of post-modern wars, it is important to understand that they are an effect of the synthesis or collision of philosophies of war characteristic of three civilisation circles: pre-industrial, industrial, and post-industrial. ${ }^{8}$

The first circle - post-industrial (the wars of the $21^{\text {st }}$ century) is formed by the states of North America, Western Europe, and the so-called Pacific Ring. It is characterised by increasing economic and political correlation, high stabilisation, and welfare. "A lack of will to offer help plays an important role in the system of values of societies of this circle. Pressure to reduce the risk of military operations, executing them with the lowest possible losses is symptomatic." There is pressure to prevent conflicts or,

7 A. Toffler, H. Toffler, Wojna i antywojna. Jak przetrwać na progu XXI wieku, [War and Anti-War: Survival at the dawn of the $21^{\text {st }}$ Century], transl. B. Budrecka, L. Budrecki, Poznań 2006, pp. 94-99.

8 B. Balcerowicz, Teorie, koncepcje wojny (i pokoju) po zimnej wojnie, [Theories, Concepts of War (and Peace) after the Cold War], [in:] R. Kuźniar (ed.), 'Porządek międzynarodowy u progu XXI wieku' [International Order at the Dawn of $21^{\text {st }}$ Century], Warszawa 2005, at pp. $473-474$. 
if they turn out to be unavoidable, keep them away from the states of the circle. $^{9}$

The second circle - industrial (the wars of the $19^{\text {th }} / 20^{\text {th }}$ century) is characterised by the $20^{\text {th }}$ century way of waging war.

Strategies (doctrines) can be oriented at constant readiness for the breakout of war. Armed forces will still be prepared to take action using $20^{\text {th }}$ century methods, which means protracted and intensive campaigns causing substantial losses. Territorial disputes remain the reason behind conflicts. ${ }^{10}$

The third circle - pre-industrial (medieval war)

is a peculiar mosaic of governments' weakness, lawlessness, and violence. It covers broad areas overcome with anarchy; failed states and bankrupted states also fit here. Armed forces, together with the regular forces, form armed groups, a more or less organised militia, private armies serving local warlords, paramilitary groups, terrorist groups, and criminal gangs. ${ }^{11}$

The concept of three civilisation circles overlapping in different configurations, with their respective philosophies of war, is accompanied by interesting differentiation into three philosophies of war: political, eschatological, and catastrophic. ${ }^{12}$ This concept was created by Anatol Rapoport.

The political philosophy of war represented by Carl von Clausewitz, who defined war as "an act of violence aimed at forcing the enemy to fulfil our will," is perceived through rationalism, nationality, and purpose. According to Clausewitz, "a decision to use the war machine to wage wars should be made basing on a rational calculation made by the competent political authorities to reach the set target." ${ }^{\text {13 }}$

The eschatological philosophy of war is based on the belief that "the 'ultimate' war will be the culmination of history, or at least its era, by which a sort of overarching general order - god's, natural or human - will be imposed." Rapoport indicates two types of this philosophy: messianistic and global. The messianistic vision assumes that "a factor which is to impose 'general order' in the world exists in history. It promises "embracing

9 Ibid., pp. 473-474.

10 Ibid., pp. 473-474.

11 Ibid., pp. 473-474.

12 P.D. Williams, op. cit., p. 149.

13 Ibid., p. 149. 
the world with fair peace," which also means "eliminating wars from the future." In the case of the global type, the new order of the world would emerge from the chaos of "the ultimate war."

The catastrophic philosophy presents war as "catastrophe influencing a part of humanity or the whole of humankind." In a given case, war can be "perceived as god's punishment or a disastrous accident in the functioning of the anarchic international system." There are two types of the catastrophic philosophy: ethnocentric and global.

The ethnocentric type shows war from the perspective of a specified national group as something which can happen to it - something that is a threat from others. This perspective of war does not bring any profit to this group; the group is left with the only option of facing the forthcoming catastrophe and trying to mitigate its results.

Within the global type, "the disaster of war may fall upon the whole of humanity, not upon one group of people. Nobody is to blame here and nobody is thought to gain profit from the catastrophe." ${ }^{.15}$

In a nutshell, Rapoport claims that "political philosophy compares war with a strategic game (for example chess), but the eschatological philosophy perceives it in the form of a mission or dramatic solution and the catastrophic philosophy comes in the form of a fire or epidemic." ${ }^{16}$

Before listing the key traits of post-modern wars, let us assume that they are an effect of a "collision" and, to a certain degree, synthesis of the types of war and war philosophy mentioned above. Post-modern war often involves using primitive tools (like machetes) and satellite telephones at the same time; depending on the stage of war or addressees, the political, eschatological, and catastrophic vision of the conflict is also often assumed.

Several traits of post-modern war, distinguishing it substantially from the war characteristic of the $19^{\text {th }}$ and $20^{\text {th }}$ centuries and being to some degree emanations of the aforementioned tendency to "hybridise" targets, means, and methods used in armed conflicts, are worth mentioning. Conscious of the spatiotemporal co-existence of a number of different generations and philosophies of war, which cross, penetrate, and confront

15 Ibid., p. 150.

16 Ibid., p. 150. 
each other on the battlefield or during non-war operations, ${ }^{17}$ the abstraction of traits characteristic of post-modern wars shall be made here by answering the key questions relating to all kinds of social relations, i.e. who, with whom, through whom, and against whom? What, for what? Where? When? Why? How, in what way?

\subsection{Who, with whom, through whom, against whom?}

As a rule, post-modern wars are not wars waged between states (not formally, at least), which does not mean that states are not indirectly involved, for example, by supporting rebels, terrorist groups, local military groups or by hiring private military companies. A party fighting in a post-modern conflict

does not directly confront enemy forces on a battlefield. It aims at striking hard using unconventional methods like terrorism (including the use of weapons of mass destruction [BMR], psychological battles (attacking enemy leaders' and social morale), information battles (cyberattacks), or economic battles (the destabilisation of the financial or stock exchange systems). ${ }^{18}$

Proxy wars constitute a special case, partly outside of the category of post-modern war. They take place when states settle the conflict not by military confrontation on their own territory but on the territory of third-party states, mainly by supporting a particular side in a civil war. Post-modern wars are most often aimed at given states and their governments, and their objective is threefold: to destabilise the domestic situation of a state, impair its position and credibility on the international stage, and decrease its trustworthiness in the opinion of inhabitants, its citizens. Therefore, in this case we are dealing with the phenomenon of the "privatisation" of war. ${ }^{19}$

17 A. Gruszczak, Hybrydowość współczesnych wojen - analiza krytyczna, [The Hybrid Character of Contemporary Wars - Critical Analysis], [in:] B. Zapała, W. Sokała (eds.), 'Asymetria i hybrydowość - stare armie wobec nowych konfliktów' [Asymmetry and Hybrid Character - Old Armies Facing New Conflicts], Warszawa 2011, at p. 11.

18 K. Korzeniewski, K. Skórczewski, P. Dzięgielewski, Akty terrorystyczne w Iraku i Afganistanie jako element wojny asymetrycznej, [Terrorist Attacks in Iraq and Afghanistan as Element of Asymmetric War], 'Lekarz Wojskowy' 2009, vol. 3, at p. 161.

19 P. Rogers, Terroryzm, [Terrorism], [in:] P.D. Williams (ed.), op. cit., at p. 170. 
In the case of post-modern war, one can observe three tendencies: the denationalisation of war, the asymmetry of violence (for example a group of terrorists against a state), and the autonomy of violence (it is not subordinate to clearly set objectives and is characterised by interim actions). The asymmetry of violence does not necessarily give a strategic advantage to the state, even as it has incomparably more resources (military and non-military, such as social legitimisation), which is due to the fact that said resources are not necessarily effectively employed in a fight against the dispersed and "amorphous" enemy that can adapt to changing circumstances with greater ease than a national state could, as the latter is obliged to abide by internal procedures, often known to the enemy, as well as legal and political norms imposed on international relations. ${ }^{20}$ Furthermore, non-state actors in asymmetric conflicts are characterised by a low susceptibility to deterrents and a degree of unpredictability in their actions.

Most often, civilians, rather than enemy armed forces, constitute the main target of aggression. During conflicts, civilians play the role of human shields, suppliers, and finally - the objective of attacks. At the end of the $20^{\text {th }}$ century, civilians accounted for about $80 \%$ of the dead and wounded, with members of armed forces making up the remaining 20\% (in classical war, these proportions were reversed). Wars waged prior to the dawn of the $20^{\text {th }}$ century saw $90 \%$ of those killed and wounded being soldiers. ${ }^{21}$ Furthermore, since the end of the Second World War, five times as many lives were claimed as a result of civil wars than by interstate conflicts. ${ }^{22}$ The objective of terrorists and various military groups is to cause the highest possible number of casualties in order to shock public opinion. This often includes the profanation of human remains, with rape becoming an effective tool for ethnic cleansing (for example, in Rwanda about a quarter of a million women were raped during a three-month conflict).

One must keep in mind that contemporary states (especially those in the West) increasingly more eagerly use military outsourcing, retaining

20 A. Wejkszner, Wojny XXI wieku. Istota współczesnych konfliktów asymetrycznych, [The Wars of the 21 $1^{\text {st }}$ Century. The Nature of Contemporary Asymmetric Conflicts], [in:] S. Wojciechowski, R. Fiedler (eds.), 'Zagrożenia asymetryczne współczesnego świata' [Asymmetric Threats of the Contemporary World], Poznań 2009, at pp. 119-127.

${ }_{21}$ H. Münkler, Wojny naszych czasów, [Wars of Our Times], transl. K. Matuszek, Kraków 2004, p. 24.

22 J. Mundy, Deconstructing civil wars: Beyond the new wars debate, 'Security Dialogue' 2011, vol. 3, pp. 279-280. 
private military companies (PMCs). The world market includes several hundred such companies, with employees in 110 states and annual proceeds exceeding 100 billion dollars. ${ }^{23}$ On a world scale, the number of PMC personnel available on demand is estimated at approximately 1.5 million regular workers plus the same number of mercenaries functioning out of PMC structures. Many PMCs are listed on the stock exchange. "The size of PMCs vary - from sole proprieties to big concerns employing hundreds of thousands of workers (G4S estimates its personnel potential at as many as 36,000 people). ${ }^{24}$

Private military companies have their HQs mainly in highly industrialised states "where the level of military know-how and military equipment is the highest and where the biggest demand is present; although, it is seldom related to using services of these companies in the given state." 25 In most cases, PMCs are seated in three places, in the case of a need to bypass statutory, state, and international regulations as well as political and legal obligations.

They hold a 'lobby seat,' which is also responsible for securing contracts, in the direct proximity of political decision centres - usually, close to capital cities or even at their centres. Their "operational points" are dispersed all over the world, so as to be closer to clients and to execute tasks more effectively. "The legal seats" of PMCs are usually located in small towns or tax havens" (lower taxes and less stringent legal control). ${ }^{26}$

It should be highlighted that mercenaries are not a new phenomenon; on the contrary, for many centuries, they were a normal part of international relations. State rulers waged war using mercenary armies hired on the "free market." The situation started to change profoundly from the $17^{\text {th }}$ century onwards, especially in the age of national states maintaining national armies made up of conscripted soldiers, based on the general need for defence.

${ }^{23}$ K. Kubiak, Słowo wstępne do polskiego wydania, [Opening Comment to the Polish Edition], [in:] R. Uesseler, 'Wojna jako usługa. Jak prywatne firmy wojskowe niszczą demokrację' [War as Service. How Private Military Companies Destroy Democracy], transl. M. Kalata, Warszawa 2008, at pp. 8-9.

24 R. Uesseler, op. cit., pp. 55-56.

25 Ibid., p. 55.

26 Ibid., pp. 58-59. 


\subsection{What? For what?}

The reason for post-modern war is with decreasing frequency all about territory or in the name of some ideology. "The gradual relative approach to the spatial factor construed as a basic source of power" is widely highlighted. There is a justified belief that establishing control over any given territory is neither tantamount to victory nor does it ensure a safe future. ${ }^{27}$ The sides of a post-modern conflict are very often motivated by matters of ethnic, racial, or religious identity. The main reason behind military and non-military actions is the defence of the (endangered) identity.

Political groups based on their own identity become nostalgic movements related to a heroic past of the given group and a memory of a once-suffered, real or imaginary, injustice. The awoken fears of historic enemies cause restlessness and a feeling of being threatened by another group of a different identity. ${ }^{28}$

Herfried Münkler, in turn, notes that "new wars smoulder, kept by an unclear coincidence of factors like personal political ambitions, an ideological approach, ethno-cultural contraries, and greed and corruption. Waged without clear targets and reasons." He adds that "this mix of reasons makes it so difficult for these wars to end and to impose stable peace." ${ }^{29}$ It is worth noting that while the "old wars" were related to the establishment of a state, the aim of "new wars" is the opposite - the destruction of a state. ${ }^{30}$

\subsection{Where?}

The concept of a battlefield where violence is accepted practically does not exist in post-modern wars. Terrorists can attack in any place and at any time.

27 J. Potulski, Geopolityka w świecie ponowoczesnym, [Geopolitics in the Post-Modern World], Częstochowa 2010, p. 187.

${ }^{28}$ K. Pawłowski, Spory i konflikty międzynarodowe, [International Conflicts and Disputes], [in:] M. Pietraś (ed.), 'Międzynarodowe stosunki polityczne' [International Political Relations], Lublin 2006, at p. 358.

${ }^{29}$ H. Münkler, op. cit., p. 15.

30 M. Kaldor, In Defence of New Wars, 'Stability' 2013, vol. 2, no 1, art. 4, p. 2, http:// dx.doi.org/10.5334/sta.at (consulted on 1.4.2015). 
Armed forces are concentrated neither in time nor in space. Conflicts often have the character of guerrilla warfare without fixed front lines. Military actions are not limited to a small piece of land and can erupt everywhere. Additionally, the internal conflict has a tendency to spread outside state borders, leading to the destabilisation of neighbouring states. ${ }^{31}$

The above statements basically relate to the classical manner of understanding the phenomenon of war as a confrontation of enemy forces in a particular physical space, with the difference being classical (modern) war is regulated by law and politics stipulating the place where the battle takes place, while the reality of post-modern war does not take these regulations into consideration. The co-existence of two major levels of conflict is an important trait of contemporary war. On the one hand, it is the previously mentioned territorial level relating to "classically construed national state and traditional ethnic, clan, or tribal communities, permanently residing on a given territory." On the other hand, there is a virtual level, having an "over-territorial, cross-border, network structure enabling communication within the network, globally promoted values, ideas and principles and also keeping and restoring its own structure." ${ }^{32}$ It should also be noted that wars waged in the virtual sphere significantly "redefine the parameters of a conflict and even eliminate some determinants, such as territory, natural resources, military organisation, and public order." In consequence, pseudo-states are created with no "traditional elements of state authority, international legal subjectivity, or hierarchical organisation" but still wield "effective instruments and methods of influencing the international environment, having an impact on the population, multiplying financial resources, and running information campaigns." ${ }^{33}$

\subsection{When?}

Seeking to answer the question of when the phenomenon of post-modern war appeared, one should bear in mind that it is impossible to arrive at

31 K. Pronińska, Współczesne konflikty zbrojne, [Contemporary Armed Conflicts], [in:] R. Kuźniar at al. (eds.), 'Bezpieczeństwo międzynarodowe' [International Security],Warszawa 2012, at p. 106.

32 A. Gruszczak, op. cit., at p. 14.

33 Ibid., p. 14. 
a precise date. It is, however, possible to connect the genesis of post-modern wars with the end of the 1980s and the end of the Cold War. Nevertheless, it seems that the most recognisable sign indicating that the world entered a new stage of armed conflict was the terrorist attack on the WTC in New York (2001), ${ }^{34}$ which became an icon of post-modern confrontation, matching the conflict between "jihad" and "McWorld," picturesquely described by American political scientist Benjamin Barber. ${ }^{35}$

It is difficult to unequivocally determine when post-modern war begins and ends. It is also difficult to speak of a culminating, decisive moment. It is not a coincidence that the name "low intensity war" is used to describe it. There is no certainty when military actions come to an end, as war lacks constant actions and terrorists can strike at the least expected moment. There are no peace treaties signed to end the conflict; there is no truce. Increasingly more often, we speak of a "peace process," where each side of the conflict is coaxed by third parties to fairly distribute the "dividend of peace." Basically, at least one side does not want to end the conflict because their target is not to defeat the enemy but rather to destabilise the situation in the state, cause displacement of the population, and derive profit from the ongoing conflict. ${ }^{36}$ What is interesting is that these remarks are not exclusively related to military conflicts between states and non-state actors, as evidenced by the undeclared wars between Russia and Georgia (2008) and Russia and Ukraine (2014-). ${ }^{37}$ Both are a gross violation of Article 1 of the Hague Convention of 1907, which stipulates that "the contracting Powers recognise that hostilities between themselves must not commence without previous and explicit warning, in the form either of a declaration of war, giving reasons, or of an ultimatum with conditional declaration of war." ${ }^{38}$

34 F.G. Hoffman, Conflict in the $21^{\text {st }}$ Century: The Rise of Hybrid Wars, Arlington 2007, p. 12.

35 See: B. Barber, Dżihad kontra McŚwiat, [Jihad vs. McWorld], transl. H. Jankowska, Warszawa 1997.

${ }^{36}$ K. Pronińska, op. cit., p. 106.

37 L. Sykulski, Rosyjska koncepcja wojen buntowniczych Jewgienija Messnera, [Russian Concept of Rebel Wars by Jewgieni Messner] 'Przegląd Geopolityczny' 2015, vol. 11, at p. 107.

38 Konwencja dotyczqca rozpoczęcia kroków nieprzyjacielskich (III konwencja haska), [Convention Relative to the Opening of Hostilities - III Hague Convention of 1907], The Hague, 18.10.1907, Polish OJ 1927, no 21, item 159. 
Contrary to classical wars, post-modern ones contain an intermediate state between war and peace. They are characterised by uncertainty and fear of renewed hostilities. In practice, it means that post-modern wars are, by default, protracted and continue for decades. One of the reasons for this is the fact that a substantial number of people have turned them into a way of life.

\subsection{Why?}

It seems that we have already partly answered the question about the reasons behind the appearance of post-modern wars by indicating the circumstances and conditions of the end of modern wars or following the intuition of Alvin and Heidi Tofflers, putting forward the thesis that "the ways of waging wars correlate with the ways of gaining material goods." ${ }^{39}$ According to these authors, none of the three "waves" (agrarian, industrial, and information) establishes a new order within the frames of production or (as a consequence) all areas of social life, including those related to war, which is a relationship that has a social character. Waves, however, do not follow each other but, in many places in the world, overlap and confront each other at the same time.

Without a doubt, among the most important reasons behind the appearance of post-modern war is the dynamic development of modern technology and its increasing popularity (inter alia as a result of lower prices). It used to be available exclusively to the richest of governments and constituted a closely guarded secret. This mainly applies to communication technologies, rather than to expensive army equipment (still unavailable to many states). Since a substantial part of post-modern warfare is waged in the virtual world (with consequences in the real world), the means for gaining and spreading information become more economically priced, of which many actors, including non-state ones, take advantage in order to influence the attitudes of others, inter alia by entering into information wars.

39 A. Toffler, H. Toffler, op. cit., p. 9. 


\subsection{How? In what way?}

As a rule, international humanitarian law is not obeyed. Terrorists correctly assume that by not recognising it they gain an advantage over the armed forces of a state, which is obliged to respect the law. This explains why terrorists readily use, for example, children in military operations, knowing that the soldiers of official armed forces will be hesitant to engage them on the battlefield.

The principle of the minimisation of costs applies to post-modern wars as it does to classical ones. However, limits that refer to the economic effectiveness of violence barely exist here. This is why they are much less costly when compared to classical wars. Terrorist units are supplied with light weapons, sold below production costs. Child-soldiers (who globally number 300,000 ) do not have to be paid, it is enough to present them with a vision of a great adventure and a bowl of food. What is more, rape during war is nothing but a practical application of the rule to make war less expensive. On the other hand, the co-existence of very expensive military supertechnologies and low-cost primitive weapons is clearly visible on contemporary battlefields. ${ }^{40}$

Significant differences concern sources of financing. Contrary to classical wars financed by states, post-modern wars derive resources from a variety of sources including loot, spoils, kidnapping, smuggling, human trafficking, "taxation" of humanitarian aid or financial aid provided by diasporas (vide: support given to UÇK by the Albanian diaspora). The goal of each side in classical warfare was to end the fighting as quickly as possible, while in post-modern warfare each side aims to spread, maintain, or persistently reignite military conflict, as it is the existence (persistence) of such operations, not the victory, that is the source of measurable political and economic profit. ${ }^{41}$ The war economy which is based on violence efficiently supersedes the normal economy. The rule stating that "war must maintain itself" applies. The conflicting sides organise a network of check points aimed at intercepting a variety of goods (including food) necessary for the functioning of "armed forces." War economies "in the short perspective are based on loot and plundering, in the longer - on different forms of slavery,

40 A. Gruszczak, op. cit., at p. 11.

${ }^{41}$ M. Kaldor, op. cit. 
and in the long perspective they develop whole sectors of a substitute economy, where exchange and violence come together." ${ }^{42}$

War propaganda is simultaneously used together with military action, but increasingly more often, instead of it. Sometimes it is as effective at reaching political goals as direct military engagement, and, at the same time, it is cheaper and does not entail losses in men and equipment. It concerns well organised media broadcasts. Either unknowingly or knowingly, the modern media, both traditional and new (internet-based, including social media, message boards, vertical portals, blogs), have become collaborators for the entities that wage war. ${ }^{43}$ It may be said that dynamic changes within the scope of communication techniques have not changed the face of contemporary warfare substantially (in the sense of their media image), ${ }^{44}$ but they have mainly influenced the manner of waging war by leading to the creation of strong relations and a strong interdependence between battlefield military leaders and political manipulation specialists, who have mastered effective techniques of influencing not only public opinion but also political decision makers. Nowadays, skilfully combining, for example, blogs with military command centres results in measurable profits, at the same time allowing for a reduction in the cost of conflicts. ${ }^{45}$

The phenomenon of so-called information wars, which aim at the "submission of elites and societies of other states in an unnoticeable way by using different secret and public channels (secret services, diplomatic and media services) of psychological influence, ideological and political diversion" ${ }^{\prime 6}$ deserve a separate mention. One of the most recent examples of an information war was the annexation of Crimea by Russia, during which "all federal TV and radio channels, newspapers, and many internet resources were launched" with the support of diplomats, politicians,

42 H. Münkler, op. cit., at p. 25.

43 Ibid. at p. 25; K. Pawłowski, op. cit., at p. 356.

44 See: U. Jarecka, Nikczemny wojownik na stusznej wojnie. Wybrane aspekty obrazu wojny w mediach wizualnych, [Evil Warrior on a Righteous War. Selected Aspects of the Image of War in Visual Media], Warszawa 2009.

45 A. Węglińska, Nowe media w sytuacji zagrożenia i konfliktu, [New Media in the Situation of Threat and Conflict], 'Rocznik Bezpieczeństwa Międzynarodowego' 2007, at pp. 202-210.

46 J. Darczewska, Anatomia rosyjskiej wojny informacyjnej. Operacja krymska-studium przypadku, [Anatomy of Russian Information War. The Crimea Operation-Case Study], 'Punkt widzenia OSW' 2014, vol. 42, at p. 5. 
political scientists, experts or representatives of the world of science, and people of culture. $^{47}$

Cyber terrorism is a method of fighting related to the functioning of information and IT systems. It should be understood as "a politically motivated attack or a threat of attack on computers, networks, or IT systems aimed at the destruction of infrastructure and threatening or forcing governments and people to execute far-going political and social objectives." At the same time, the authors cited add that "it is also using the internet by terrorist organisations to communicate, spread propaganda and disinformation." ${ }^{48}$ The spectrum of means used by cyber terrorists is surprisingly broad, starting from disabling elevators in public administration buildings to acquiring control over the management of the technological processes in nuclear plants.

\section{Science of international relations and theory of international law against post-modern war}

In this part, we try to answer the question about what models can be suggested by the science of international relations and the theory of international law to present and explain the phenomenon described above. To reach this goal, we start with a thought on human nature. As this idea may be surprising, we will attempt to demonstrate that this direction is not only relevant to the issue at hand but also of fundamental importance when considering the above mentioned theoretical constructions in the context of post-modern wars. As Bertrand Russell noted, a state is an "abstraction" which "does not feel pleasure or pain, it is not familiar with hopes or fears, what seems to us as its target is truly a target of individuals who manage it. When we think in precise categories, not abstract ones, it turns out that the 'state' includes people having more power than given to most mortals." ${ }^{49}$ If we assume that states have more or less the same

47 Ibid., at p. 5.

48 A. Bogdał-Brzezińska, M. F. Gawrycki, Cyberterroryzm i problemy bezpieczeństwa informacyjnego we wspótczesnym świecie, [Cyberterrorism and Information Security Problems in the Contemporary World], Warszawa 2003, p. 73.

49 B. Russell, Władza i jednostka, [Authority and the Individual], transl. H. Jankowska, Warszawa 1997, p. 121. 
rights as humans, we can also imagine a society of states more or less the same as a society of people. ${ }^{50}$

\subsection{The philosophical foundations of IR paradigms and international law}

We would, therefore, like to start with the fact that people (and, more precisely, human nature) have not changed a great deal over the centuries. This means that, as in the past, they remain imperfect and their skills have not changed significantly. During the development of civilisations, changes and developments were born out of the need to improve the quality of human lives, with various degrees of success, and some of the changes generated serious problems, something that we occasionally experience ourselves. People, in general, remained unchanged, with the same weaknesses and passions. These limits and passions were, and still remain, the source of decisions and actions taken by people. Consequently, human desires arise from overgrown ambition, envy, weakness, or fear. Obviously, we give only some sources, conscious of the fact that the full list is rather long. For the purposes of this paper, we assume that in the past life was as described by Jean-Jacques Rousseau for whom cooperation between people was necessary to satisfy our growing needs. However, according to Rousseau, a person experiences their own weakness, which stems from their greed, because where needs bring people together, passions separate them. The more they became enemies, the more they cannot live without each other. According to Rousseau, this was the way in which the first social bonds appeared. ${ }^{51}$ The French philosopher believed that this state of affairs consisted of "many relations without measure, rules, persistency, which people constantly violate and change" and when "one makes an effort to embalm them, a hundred others make an effort to

50 M. Walzer, Prawo i porządek w społeczności międzynarodowej, [Law and Order in International Society], [in:] T. Żuradzki, T. Kuniński (eds.), 'Etyka wojny. Antologia tekstów' [Ethics of War. Anthology of Texts], Warszawa 2009, at p. 151.

51 J.J. Rousseau, Umowa społeczna oraz Uwagi o rządzie polskim. Przedmowa do "Narcyza". List o widowiskach. List o opatrzności. Listy moralne. List do arcybiskupa de Beaumont. Listy do Malesherbesa, [The Social Contract, Considerations on the Government of Poland, Foreword to Narcissus, Letter to Alembert on the Theatre, Letters on Providence, Letters on Morality, Letter to Christopher de Beaumont, Archbishop of Paris, Letters to Malesherbes], transl. B. Baczko at al., ed. and foreword B. Baczko, Warszawa 1966, p. 167. 
destroy them." ${ }^{2}$ Therefore, common society has never been any help for man, who, as a result of changes, has become an "ill-fated creature." Man, "weak, straying, squashed, crushed by the multitude of others, finds no shelter, no anchor for his weakness." Even in rejecting such a pessimistic vision, we should rather agree with Rousseau's statement that common society "gives no new power to anybody apart from those who already have too much of it." ${ }^{\text {"3 }}$ We present such a point of view because the described paradox finds evidence in an abundance of examples in international relations: destruction, building; destroying to build, building to destroy... But these are not states, understood as some abstract concepts that suffer; these are people. The following observation by Bertrand Russell serves as a supplement to this sad diagnosis: "humanity invented slavery, the rich of this world believe that they can reach happiness by means which make others unhappy." ${ }^{24}$ These words are still relevant today. Dissimilarities are a serious problem, seemingly unsolvable in a way that is acceptable to the sides of current and past conflicts, mainly due to the fact that this problem is completely overlooked by many.

Continuing the considerations based on this point of view, it is safe to assume that people lacked a "comfortable life in social apartments assigned by history" ${ }^{\prime 5}$ and that this state of unhappiness continues. Nothing in particular has happened to change this situation of permanent insecurity, and it is doubtful that anything will happen. The "silence" may only prove that this state of unhappiness is dormant. The "silence" is only a herald of an inevitable eruption. An existential inconvenience perceived in different ways and having different conditions (so different that it is not only ignored but simply unnoticed by many), constituted and constitutes probably the most convincing explanation of why people "drew images of perfection, of a better place, for ages according to what they lacked in their lives and what bothered them the most," locating this "place of fulfilment (...) once in the future, once in the past and, finally, once, in a different contemporary order." ${ }^{56}$ Giovanni Sartori claimed that people were always accompanied by a longing for a better, "ideal world" or basically "an ideal counter world"

52

53

54

55 377.

Ibid., at p. 377.

Ibid., p. 168.

Ibid., p. 168.
B. Russell, op. cit., p. 125.

S. Lem, Fantastyka i futurologia, [Fantasy and Futurology], vol. 2, Kraków 1989, p. 
and designing it ${ }^{57}$ because, as François Jacob wrote, having such an "ideal and coherent vision of the world" is probably a requirement of the human mind as its absence causes fear and schizophrenia. ${ }^{58}$

It cannot be forgotten that these dreams of a better, safer life are followed by a desire for their fulfilment. Fear and insecurity have made security one of the main desires of man, and pursuing security became one of the main driving forces in social evolution. Undoubtedly, security determined and continues to determine the survival of a person or society. Of course, it ought to be noted that the meaning of the word survival has changed over the course of the development of civilisation. ${ }^{59}$ To understand the wider issue of security it is necessary to single out its basic dimensions: (1) objective (unitary, national, international, and global), (2) subjective (values, means, tools, and state activity), (3) process (politics, different strategies, and correlations), and (4) structural-execution (organisations, institutions, and actions). ${ }^{60}$ It should be noted that the dynamic growth of the objective spectrum is a distinctive characteristic of contemporary security. ${ }^{61}$ It was caused by radical changes in the security environment. Due to this fact and apart from the military, the following types of threats are considered: political, economic, social, ethnic, cultural, and environmental. Additionally, these categories have become more precise when information on energy, demographics, and data security is included. ${ }^{62}$ This attitude does not fully meet the meaning of the term security, which is the subject of our paper as under the influence of globalisation, responsible for the

57 G. Sartori, Teoria demokracji, [Theory of Democracy], transl. P. Amsterdamski, D. Grinbeg, Warsaw 1998, p. 83.

58 F. Jacob, Gra możliwości. Esej o różnorodności życia, [Game of Possibilities. Essay on Diversity of Life], transl. M. Kunicki-Goldfinger, foreword W. J. H. Kunicki-Goldfinger, Warszawa 1987, p. 25.

59 J. Wolanin, Zarys bezpieczeństwa obywateli. Ochrona ludności na czas pokoju, [Outline of Security of Citizens. Protecting People in Time of Peace], Warszawa 2005, p. 13.

60 E. Nowak, Bezpieczeństwo narodowe - istota, zakres, uwarunkowania, [National Security: Substance, Scope, Conditions], [in:] T. Jemioło, K. Rajchel (eds.), 'Bezpieczeństwo narodowe i zarządzanie kryzysowe w Polsce w XXI wieku' [National Security and Crisis Management in Poland in 21 $1^{\text {st }}$ Century], Warszawa 2009, at p. 66.

61 Ibid., at p. 66.

62 T.R. Aleksandrowicz, Strategie bezpieczeństwa w cyberprzestrzeni. Cyberwojny, [Security Strategies in Cyberspace. Cyberwars], [in:] K. Liedel, P. Piasecka, T.R. Aleksandrowicz (eds.), 'Sieciocentryczne bezpieczeństwo. Wojna, pokój i terroryzm w epoce informacji' [Networkcentric Security. War, Peace, and Terrorism in the Era of Information], Warszawa 2014, at p. 39. 
internationalisation of internal problems and, at the same time, and the internalisation (and perceiving as one's own) of international problems, the borders of "internal" and "external" phenomena in international relations within security matters are becoming blurred. ${ }^{63}$

Therefore, it is correct to use the category of national security or state security, threatened by the coincidence of internal events or events in international relations during which: (1) there is a high probability of limitation or loss of the conditions of undisturbed existence and internal development or violation or loss of the independence of the state and its position as a partner in international relations, as a result political, psychological, economic, or military violence; or (2) actions or a sequence of events drastically threaten, in a relatively short period of time, the quality of life of residents of the given states or carry a substantial threat of limiting the political choices by the government of the country or by NGOs. ${ }^{64}$

This approach to the subject is unique in that it discloses the broad spectrum of threats which can reduce the feeling of security. At the same time, their division into external and internal loses its importance. These threats highlight desirable activities on the part of the state or international community that are necessary in order to maintain a proper balance and take appropriate security or defensive measures. The scale of threats cannot be overstated: not only have we forgotten that prior to 1945 the history of Europe was a history of wars and signed, broken, or reversed agreements, while the "borders of European states separated opposing states and that an ideal border was one which formed a strategic line, easy to defend." ${ }^{65}$ Convinced of our unity and, in some cases, of our cultural superiority, we have also forgotten that "each nation has its own natural philosophy for its own use and is convinced that [their philosophy] is transmitted in the best possible way, which leads to slaughter and murder more often than it does to concord and peace." ${ }^{66}$ Undoubtedly, internal conflicts around civilisations are implied by problems which occur within them. ${ }^{67}$ We for-

63 W. Kostecki, Strach i potęga. Bezpieczeństwo międzynarodowe w XXI wieku, [Fear and Power. International Security in 21 ${ }^{\text {st }}$ Century], Warszawa 2012, at p. 64.

64 E. Nowak, op. cit., p. 68.

65 P. Wandycz, L. Frendl, Zjednoczona Europa. Teoria i praktyka, [United Europe. Theory and Practice], London 1965, p. 21.

66 J.J. Rousseau, op. cit., p. 173.

67 D. Miłoszewska, Zderzenie cywilizacji - mit czy rzeczywistość?, [Clash of Civilisations Myth or Reality?], [in:] W. Malendowski (ed.), 'Świat współczesny. Wyzwania, zagrożenia i współzależności w procesie budowy nowego porządku międzynarodowego' 
get that these different national and non-national narrations are equal in terms of the scope in which every group accepting them recognises their genuineness and value, that is certainly felt by their members. The question of identity stems from "the feeling of instability of existence and 'manipulable,' 'incompletely defined,' 'uncertain' and 'not final' forms of it." ${ }^{\prime 68}$ It is not a question of whether or not it is our place to impose any vision of international order. Undoubtedly, we are entitled to do so, as it is hard to deprive ourselves of the right to security, finding justifiable actions destructive to us. However, we must be aware of the fact that this international order is nothing more than our vision of this order and, due to this fact, we will only pursue our own security goals and of those eager to share our fears. All others, less inclined to accept our alternative vision of security and the necessity to confront it, will, in the best case scenario, refuse to participate in its creation. States representing different civilisations cannot, and even do not want to, hold a dialogue because they claim that their respective values are the most important while foreign cultures and traditions are uninteresting, if not irrelevant. ${ }^{69}$

M. Walzer claims that the international community is an imperfect creation. It can be compared to an "unsure building based on a fundament of rights," because "its construction, like the construction of a state, was created as a result of political conflict, activity based on cooperation and trade. The entirety is shaky and unstable, because it is not bound by authority." M. Walzer indicates that it is similar to state society, as "it contains people (sometimes) living in peace, determining conditions of their own existence, negating and haggling with neighbours." The difference between international and state communities is that "every conflict brings a threat of collapse of the whole structure." It is due to the fact that aggression "strikes the international community directly and it is much more dangerous than intrastate crime as there is no police present in this case." This means that police authority is held by all members of the international community, and, because of that, they "must depend on themselves and on each other," which is not the issue of refraining from, stopping, or promptly quashing aggression because, as M. Walzer notes,

[Contemporary World. Challenges. Threats and Codependence in the Process of Building New International Order], Poznań 2008, at p. 316.

68 Z. Bauman, Ponowoczesne wzory osobowe, [Post-Modern Personal Patterns], 'Studia Socjologiczne' 1993, vol. 2, at pp. 7-8.

69 D. Miłoszewska, op. cit., at p. 318. 
it would be "as if the police stopped a murderer who killed only one or two people and let him go free." The rights of member states of the international community must be confirmed because only pursuant to these rights may we talk of the existence of society, and if these rights cannot be exercised, the international community falls into war or transforms into a kind of "world tyranny."

\subsection{Post-modern wars in the perspective of IR paradigms}

Seeing as this deficit (gap) is also a difficult challenge to overcome, let us try to ascertain, from the perspective of the above conditions, the usefulness of theories of international relations, such as realism, liberalism, globalism, and constructivism, in explaining post-modern wars.

\subsubsection{Realistic paradigm}

A realistic paradigm consists of two elements: (1) the independence of a state and (2) international anarchy (the complete absence of world governments or regimes or even a dense network of regional integration regimes). Realists see the state from the perspective of the ability to fulfil tasks generated by anarchy (states want to survive in a dangerous world, so they struggle for more power). From the perspective of realistic theory, wars and conflicts, or threats stemming from them, are a natural state. Robert Łoś indicates three forms of state activity: (1) preparations for war, (2) participation in war, (3) liquidation of its results. The main target of the state is to secure the maximum of power, as a precondition to reaching the other goals, and it is a reference point for any further actions or decisions. The inevitability of war, arising from the presented diagnosis of the international reality, is not tantamount to states seeking war, because states tend to act reasonably while executing their foreign policy. They behave in a way that is most profitable to them, and ensuring security, rather than war in itself, is the goal. The key categories for realists are: national interest, power, independence, and military strategy. The goal of the state is to pursue power, as it determines the position of the state 
in the system. In order to accomplish that goal, states estimate their own relative power, which means that rivalry between states is stipulated by the principle of balance of power. If it is so, no state will agree to another state gaining advantage over an enemy. ${ }^{71}$ To some extent, from the perspective of maintaining a peculiar efficiency of the state, realism seems to be a concept adequate to the situation created by post-modern wars. Focusing only on the mechanism of organisation, which constantly processes data from the environment, monitors the type, quantity, and seriousness of threats while simultaneously seeking the optimal ways of countervailing them, we should come to the conclusion that in the realistic paradigm it is possible to find a model pattern of organisation prepared to function in a state of permanent threat, pursuing, at the same time, a high level of security. Nevertheless, with realism gaining independence, the key category concentrates on conflicts between states. Due to this, it may seem that to realists the only area of interest is the power of each state. If so, they lose sight of a significant number of threats that can be described using the concept of non-state violence. Therefore, the balance of power perceived by realists becomes apparent.

\subsubsection{Liberal paradigm}

Liberals, on the other hand, indicate the prosperity and well-being of society as the main targets for the state. This point of view results in them paying attention predominantly to economic and social issues. To liberals, wars are simply unprofitable, as they generate debt and losses for industry, restrict trade and reduce the population. Theories of democratic liberalism assume that democracies do not wage wars for two reasons: (1) institutional and (2) normative. In accordance with the institutional argument, the republican system should be in power in every state (Kant's thesis). As this system ensures freedom, citizens would oppose war so as not to risk their lives or bear any costs. Democratic institutions themselves, including the balance of power, political pluralism, and public opinion, according to liberals constitute a reasonably effective barrier against war.

71 R. Łoś, Wojna i konflikt zbrojny w teoriach stosunków międzynarodowych, [War and Armed Conflict in Theories of International Relations], [in:] R. Łoś, J. Reginia-Zacharski, Współczesne konflikty zbrojne, [Contemporary Armed Conflicts], Warszawa 2010, at pp. 34-35. 
The normative argument, in turn, assumes that there is a propensity for peaceful behaviour in democratic states, which leads to them perceiving other democracies positively; consequently, in crisis situations, they opt for maintaining peace and open negotiations. It is, however, indicated that in some specific conditions the internal situation in democratic states can make governments wage war, for example, in order to "increase the cohesiveness of society" or "to enhance their own position." Rulers may also neglect to account for the costs of war, which stems from different prejudices obscuring the said costs. They can also personally benefit from a war and base their decision to enter into one on a subjective calculation of risks and costs of war. ${ }^{72}$ While analysing liberalism from the perspective of utility to explain post-modern wars, it should be noted that this theory highlights the basic dilemma of Western democracies, but only in the external dimension and exclusively from the perspective of these states. From the perspective of liberalism, the thesis on the necessity of spreading democracy to reduce the threat of conflict remains relevant as long as it can be assumed that the groups to be democratised by force will share the enthusiasm of their "liberators" and so the democratising actions will have an effect. The example of the war in Iraq is an example of a reverse scenario, and it additionally confirms that democratic slogans are only a disguise, if we can only see the economic targets behind the idea of spreading democracy. Liberalism directed internally, as shown by the example of the European Union, fails to serve its purpose; France is a good example here. The open model of identity also confirms the weakness of democracy. Supporting the constitution alone ${ }^{73}$ turns out to be insufficient as, in fact, nothing stops this European-tradition-based system from being changed by democratic means. If only voting is to be the substance of democracy, this system becomes nothing more than a "voting machine." Where are the correcting mechanisms then? Is equality such a factor? Absolutely not, unless democratic societies specify what they understand under the term of equality and on the condition that they would be willing to partake in such a debate. Finally, liberalism concentrates excessively on the wellbeing of societies and falls into the trap of consumerism. Purchasing power becomes more important than values. Such a society is dormant and unable

73 P. Sériot, Ethnos i demos: dyskursywne konstruowanie zbiorowej tożsamości, [Ethnos and Demos. Discursive Construction of Collective Identity], transl. A. Dutka, 'Teksty Drugie' 1994, vol. 1, at pp. 136-137. 
to defend anything, especially when it turns out that, apart from the level of life, there is nothing to defend. This, however, is a situation of a hostage rather than a defender.

\subsubsection{Globalist paradigm}

As far as globalist concepts are concerned, they explain the need to unwind the tense internal situation of European states by the necessity of directing it outside. According to globalists (mainly neo-Marxists), an excess of accumulated capital causes the fact that states undertake the execution of investments and expansion into the Third World. They seek markets for their own industrial output, as the foregoing markets are not able to accept it. In this manner, imperial politics lead to war as a necessity to protect foreign investments necessitates an increase in military spending, financed from surplus gained from taxation. These actions adversely affect the poorest of social groups because if the state allotted the said surplus to decreasing inequality, it could not be reserved for imperial targets anymore. Globalists claim that the need to contend for foreign markets would disappear as a result, followed by the reasons behind imperialism and wars. ${ }^{74}$ When examining conflicts in categories of increasing or losing economic influence, it must be shown that globalism itself seems to be a rather creative paradigm, at least at the level of diagnosing the economic conditions of wars. In light of this concept, the conflict in Ukraine may be analysed as a battlefield of war of influence, waged between Russia and the European Union. It is also apparent that applying this approach restricts ones vantage point and makes it impossible to see other, equally important, conditions, such as the question of a constructed identity and the feeling of belonging to a group of Russian nations.

\subsubsection{Constructivist paradigm}

Constructivism presents itself in a fairly promising way, compared to previously mentioned theories. According to constructivists, their approach enables a wider development of categories belonging to realism. The basic

$74 \quad$ R. Łoś, op. cit., pp. 42-43. 
assumption of constructivism is the conviction that security is a social construct. Therefore, it is impossible to say in an "abstractive" and "general" way what the sources of threat in world politics are, as these are the leaders of states who, repeatedly, "basing on the idea of intrastate identity, designate other states as 'friends' or 'enemies' in order to address them in an appropriate manner later." ${ }^{75}$ It is the constructivist's "conditioning of security by identity relations" that leads to the assumption that "intangible factors and perceptions usually decide on the construction and execution of security in world politics." The most important perception factors are the assumed social norms, which are "the patterns of correct or eligible behaviour, which are jointly wanted by actors coming under a given identity." 76 If constructivism seems to take different perspectives into consideration as equal (created constructs), then this approach seems to be most useful to analyse post-modern wars. It sees life as non-static and an appropriate definition of threats is possible only through learning what and how others think, what constructs they find effective and what imperatives derive from them, rather than limiting oneself to one point of view. This kind of pluralism seems to be reduced by the dominance of the conviction of what life should look like and how it should be organised. Obviously, this is not a mistake. Assuming that constructivism is to be functional and useful, we should determine our needs. However, we should resign from the incorrect assumption that others pursue, or will pursue, the same goals as we do. Only this direction can promote the search for a world balance. Life and reality can be modified, but, at times, the costs far outweighs the profits, which is why, sometimes, it is better to accept it as it is.

\section{Conclusions}

Enlarging the political power of states by conquering new territories was the main target of modern wars, however, post-modern wars have a non-state character, being the result of what may be called "civilisational changes." Both sides of post-modern conflicts still include state governments, but they are now challenged by internal opposition groups.

75 M. McDonald, Konstruktywizm, [Constructivism], [in:] P.D. Williams (ed.), op. cit., at p. 61 .

76 Ibid., at pp. 62-63. 
An increasing number of private wars waged only among non-state actors should also be mentioned in this context. These changes are a consequence of the ongoing democratisation process and the rise of consumerism, which seems to inevitably follow. In the light of arguments based on these facts, it may be assumed with a high level of probability that traditional wars are simply not profitable anymore. At the same time, the "softening" of human characters (some, at least) by civilisation, the dominant position of the rational approach leading to frequent calculations and an awareness of a lack of the profitability of conflict has not eliminated sources of conflict, which seem to have remain unchanged. Furthermore, a lack of the formal presence of states in such conflicts does not mean that states are not involved. From this perspective, the post-modern war may be seen as more comfortable and, what is particularly important, more profitable, as it is significantly less costly. The post-modern war also escapes the rules of international law, which is not without importance, and remains well-suited for one side engaged in such a conflict, as it is followed by inactivity on the part of entities (states, international organisations) which are widely thought to be bound to react in order to defend the international order. Finally, such a war gives a semblance of democracy being maintained, which appears to profit the hidden sides of conflicts, which are their actual beneficiaries.

\section{Bibliography}

T.R. Aleksandrowicz, Strategie bezpieczeństwa w cyberprzestrzeni. Cyberwojny [in:] K. Liedel, P. Piasecka, T.R. Aleksandrowicz (eds.), 'Sieciocentryczne bezpieczeństwo. Wojna, pokój i terroryzm w epoce informacji', Warsaw 2014.

B. Balcerowicz, Teorie, koncepcje wojny (i pokoju) po zimnej wojnie, [in:] R. Kuźniar (ed.), 'Porządek międzynarodowy u progu XXI wieku', Warszawa 2005.

B. Barber, Dżihad kontra McŚwiat, Warszawa 1997.

Z. Bauman, Ponowoczesne wzory osobowe, 'Studia Socjologiczne' 1993, vol. 2.

A. Bogdał-Brzezińska, M. F. Gawrycki, Cyberterroryzm i problemy bezpieczeństwa informacyjnego we wspótczesnym świecie, Warszawa 2003.

J. Darczewska, Anatomia rosyjskiej wojny informacyjnej. Operacja krymska - studium przypadku, 'Punkt widzenia OSW' 2014, vol. 42.

A. Gruszczak, Hybrydowość wspótczesnych wojen - analiza krytyczna, [in:] B. Zapała, W. Sokała (eds.), 'Asymetria i hybrydowość - stare armie wobec nowych konfliktów', Warszawa 2011.

P. Hassner, Koniec pewników. Eseje o wojnie, pokoju i przemocy, Warszawa 2002.

F.G. Hoffman, Conflict in the 21 $1^{\text {st }}$ Century: The Rise of Hybrid Wars, Arlington 2007.

F. Jacob, Gra możliwości. Esej o różnorodności życia, Warszawa 1987. 
U. Jarecka, Nikczemny wojownik na słusznej wojnie. Wybrane aspekty obrazu wojny $w$ mediach wizualnych, Warszawa 2009.

M. Kaldor, In Defence of New Wars, 'Stability' 2013, vol. 2, no 1.

K. Korzeniewski, K. Skórczewski, P. Dzięgielewski, Akty terrorystyczne w Iraku i Afganistanie jako element wojny asymetrycznej, 'Lekarz Wojskowy' 2009, vol. 3.

W. Kostecki, Strach i potęga. Bezpieczeństwo międzynarodowe w XXI wieku, Warszawa 2012.

K. Kubiak, Słowo wstępne do polskiego wydania, [in:] R. Uesseler, 'Wojna jako usługa. Jak prywatne firmy wojskowe niszczą demokrację’ Warszawa 2008.

S. Lem, Fantastyka i futurologia, vol. 2, Kraków 1989.

R. Łoś, Wojna i konflikt zbrojny w teoriach stosunków międzynarodowych, [in:] R. Łoś, J. Reginia-Zacharski, 'Współczesne konflikty zbrojne’, Warszawa 2010.

M. McDonald, Konstruktywizm, [in:] P.D. Williams (ed.), 'Studia bezpieczeństwa', Kraków 2012.

D. Miłoszewska, Zderzenie cywilizacji - mit czy rzeczywistość?, [in:] W. Malendowski (ed.), 'Świat współczesny. Wyzwania, zagrożenia i współzależności w procesie budowy nowego porządku międzynarodowego', Poznań 2008.

J. Mundy, Deconstructing civil wars: Beyond the new wars debate, 'Security Dialogue' 2011, vol. 3.

H. Münkler, Wojny naszych czasów, Kraków 2004.

E. Nowak, Bezpieczeństwo narodowe - istota, zakres, uwarunkowania, [in:] T. Jemioło, K. Rajchel (eds.), 'Bezpieczeństwo narodowe i zarządzanie kryzysowe w Polsce w XXI wieku', Warszawa 2009.

K. Pawłowski, Spory i konflikty międzynarodowe [in:] M. Pietraś (ed.), 'Międzynarodowe stosunki polityczne', Lublin 2006.

N. Polat, Peace as War, 'Alternatives: Global, Local, Political' 2010, vol. 35.

J. Potulski, Geopolityka w świecie ponowoczesnym, Częstochowa 2010.

K. Pronińska, Wspótczesne konflikty zbrojne, [in:] R. Kuźniar at al. (eds.), 'Bezpieczeństwo międzynarodowe', Warszawa 2012.

P. Rogers, Terroryzm, [in:] P.D. Williams (ed.), 'Studia bezpieczeństwa', Kraków 2012.

J.J. Rousseau, Umowa społeczna oraz Uwagi o rządzie polskim. Przedmowa do "Narcyza". List o widowiskach. List o opatrzności. Listy moralne. List do arcybiskupa de Beaumont. Listy do Malesherbesa, ed. and foreword B. Baczko, Warszawa 1966.

B. Russell, Władza i jednostka, Warszawa 1997.

G. Sartori, Teoria demokracji, Warszawa 1998.

P. Sériot, Ethnos i demos: dyskursywne konstruowanie zbiorowej tożsamości, 'Teksty Drugie' 1994, vol. 1.

L. Sykulski, Rosyjska koncepcja wojen buntowniczych Jewgienija Messnera, 'Przegląd Geopolityczny' 2015, vol. 11. 
J.M. Taw, Planning for Military Operations Other Than War: Lessons from US Army Efforts, 'Australian Defence Force Journal' 1999, vol. 134.

A. Toeffler, H. Toeffler, Wojna i antywojna. Jak przetrwać na progu XXI wieku, Poznań 2006.

M. Walzer, Prawo i porządek $w$ społeczności międzynarodowej, [in:] T. Żuradzki, T. Kuniński (eds.), 'Etyka wojny. Antologia tekstów', Warszawa 2009.

P. Wandycz, L. Frendl, Zjednoczona Europa. Teoria i praktyka, London 1965.

A. Wejkszner, Wojny XXI wieku. Istota wspótczesnych konfliktów asymetrycznych [in:] S. Wojciechowski, R. Fiedler (eds.), 'Zagrożenia asymetryczne współczesnego świata', Poznań 2009.

A. Węglińska, Nowe media w sytuacji zagrożenia i konfliktu, 'Rocznik Bezpieczeństwa Międzynarodowego' 2007.

P.D. Williams, Wojna [in:] P.D. Williams (ed.), 'Studia bezpieczeństwa', Kraków 2012.

J. Wolanin, Zarys bezpieczeństwa obywateli. Ochrona ludności na czas pokoju, Warszawa 2005. 